\title{
Specialized nursing terminology for the care of people with metabolic syndrome
}

\author{
Terminologia especializada de enfermagem para o cuidado de pessoas com síndrome metabólica \\ Terminología especializada de enfermería para el cuidado a la persona con síndrome metabólica
}

Nuno Damácio de Carvalho Félix ${ }^{1,2}$ (1) Maria Naiane Rolim Nascimento ${ }^{3}$ (1) Natana de Morais Ramos ${ }^{1}$ (1) Célida Juliana de Oliveira ${ }^{3}$ (D) Maria Miriam Lima da Nóbrega ${ }^{1}$ (1)

${ }^{1}$ Universidade Federal da Paraíba, Programa de Pós-Graduação em Enfermagem. João Pessoa, PB, Brasil.

${ }^{2}$ Universidade Federal do Recôncavo da Bahia, Centro de Ciências da Saúde. Santo Antônio de Jesus, BA, Brasil.

${ }^{3}$ Universidade Regional do Cariri, Programa de Pós-Graduação em Enfermagem. Crato, $\mathrm{CE}$, Brasil.

\begin{abstract}
Objective: To build a specialized nursing terminology for the care of people with metabolic syndrome in Primary Health Care. Method: Methodological study, based on the identification of nursing concepts for the care of people with the syndrome, validation of concepts with nurses experts, and cross-mapping with the early concepts of ICNP ${ }^{\circledR} 2017$. Results: Of the concepts extracted, 489 involved psychobiological, psychosocial, and psycho-spiritual needs. Of these, 441 concepts were validated and subjected to mapping and analysis of similarity and comprehensiveness, which allowed the elimination of concepts considered synonyms, culminating in 389 concepts related to the needs of people with metabolic syndrome, in which $43.7 \%$ of validated concepts were not contained in the 2017 version of the ICNP ${ }^{\circledR}$. Of the constant and non-constant concepts, $42.3 \%$ were classified in the Action axis, followed by the Focus axis (34.9\%). Conclusion and implications for practice: With the achievement of the objective, there is the advance in knowledge about the use of ICNP ${ }^{\circledR}$, with a proposal to standardize professional language for the care of people with metabolic syndrome, with the potential to increase Primary Health Care information systems with indicators of nursing care for people with aggregation of cardiovascular risk factors.
\end{abstract}

Keywords: Nursing; Terminology; Metabolic Syndrome; Primary Health Care.

\section{RESUMO}

Objetivo: Construir uma terminologia especializada de enfermagem para o cuidado de pessoas com síndrome metabólica na Atenção Primária à Saúde. Método: Estudo metodológico, realizado a partir da identificação dos conceitos de enfermagem para o cuidado à pessoa com a síndrome, validação dos conceitos com enfermeiros especialistas e mapeamento cruzado com os conceitos primitivos da CIPE ${ }^{\circledR}$ 2017. Resultados: Dos conceitos extraídos, 489 envolveram as necessidades psicobiológicas, psicossociais e psicoespirituais. Destes, 441 conceitos foram validados e submetidos ao mapeamento e à análise de similaridade e abrangência, a qual possibilitou eliminação de conceitos considerados sinônimos, culminado em 389 conceitos relacionados às necessidades de pessoas com síndrome metabólica, em que 43,7\% dos conceitos validados não constavam na versão 2017 da CIPE ${ }^{\circledR}$. Do total de conceitos constantes e não constantes $42,3 \%$ foram classificados no eixo Ação, seguido do eixo Foco (34,9\%). Conclusão e implicações para a prática: Com o alcance do objetivo, têm-se o avanço no conhecimento sobre a utilização da CIPE ${ }^{\circledR}$, com uma proposta de uniformização da linguagem profissional para o cuidado de pessoas com síndrome metabólica, com potencial para incrementar sistemas de informação da Atenção Primária à Saúde com indicadores do cuidado de enfermagem para pessoas com agregação de fatores de risco cardiovasculares.

Palavras-chave: Enfermagem; Terminologia; Síndrome Metabólica; Atenção Primária à Saúde.

\section{RESUMEN}

Objetivo: Construir una terminología especializada en enfermería para el cuidado de personas con síndrome metabólico en Atención Primaria de Salud Método: Estudio metodológico, basado en la identificación de conceptos de enfermería para el cuidado de personas con síndrome, validación de conceptos con enfermeros expertos y mapeo cruzado con los primeros conceptos de CIPE ${ }^{\otimes}$ 2017. Resultados: De los conceptos extraídos, 489 involucraron las necesidades psicobiológicas, psicosociales y espirituales. De estos, 441 conceptos fueron validados y sometidos a mapeo y análisis de similitud y exhaustividad, lo que permitió la eliminación de conceptos considerados sinónimos, que culminaron en 389 conceptos relacionados con las necesidades de las personas con síndrome metabólico, de los cuales el 43.7\% de los conceptos validados no constaban en la versión 2017 de la $\mathrm{CIPE}^{\circledast}$. Del total de conceptos constantes y no constantes, el $42,3 \%$ se clasificó en el eje Acción, seguido del eje Enfoque $(34,9 \%)$. Conclusión e implicaciones para la práctica: con el logro del objetivo, existe un avance en el conocimiento sobre el uso de $\mathrm{CIPE}{ }^{\circledast}$, con una propuesta para estandarizar el lenguaje profesional para la atención de personas con síndrome metabólico, con el potencial de mejorar los sistemas de información de Atención Primaria de Salud con indicadores de atención de enfermería para personas con agregación de factores de riesgo cardiovascular.

Palabras clave: Enfermería; Terminología; Síndrome Metabólico; Atención Primaria de Salud 


\section{INTRODUCTION}

The metabolic syndrome involves the aggregation of significant cardiovascular risk markers, with identification of at least three criteria such as increased abdominal circumference, elevated fasting blood glucose, blood pressure, triglycerides, and/or reduced high density cholesterol. ${ }^{1}$ There is still insufficient data on its prevalence, with variations according to the region, the population (sex, age, race and ethnicity), the environment (urban or rural) and the parameters and criteria adopted for its identification.

In Brazil, about $30 \%$ of the population aged between 19 and 64 years have metabolic syndrome, ${ }^{2}$ demanding care for disease prevention and health promotion, with the potential to generate valid indicators, derived from the records made by health professionals, in particular, the nurse working in Primary Health Care. This constantly accompanies several groups of individuals with the syndrome in health programs in Primary Care ${ }^{1}$ collaborating with the rise of quality of care and knowledge about concepts/terms related to nursing classification systems.

Many concepts/terms are widely used and new ones are identified, but these may not be valid for the clinic. Technical-scientific concepts are expressed, but it is necessary to structure them according to their usefulness and scientific characterization in the context of Nursing, enabling the standardization of professional language. However, there is a limitation involving the incipient record in the medical records and the divergence as to valid concepts/terms, which hinders advances in clinical practice, but which can be met, a priori, by using the literature and/or official documents of the area for extracting indicators. ${ }^{3}$

In this perspective, Nursing is in a process of transformation and development, which strengthens the recognition of this as a science, ${ }^{4}$ while increasing practice in scientific evidence and consolidating itself through specific terminology that establishes the definition and description of phenomena and actions. However, the lack of uniformity in this vocabulary has hindered progress in knowledge, ${ }^{5}$ which justifies the relevance of the development of this study.

The use of standardized language in Nursing is a primordial object of the International Council of Nurses (ICN) and it has been identified as one of the means for the profession to achieve the conformation of science, with systematic care and directed to health priorities inserted in the spectrum of action in the most diverse scenarios and using classification systems in nursing. The International Classification for Nursing Practice (ICNP ${ }^{\circledR}$ ), started in 1989 by the ICN and inserted, since 2008, in the Family of International Classifications of the World Health Organization, as Related Classification. ${ }^{6}$ The 2019 version of ICNP ${ }^{\circledR}$ presents 4,475 concepts, of which 2,035 are pre-coordinated concepts (related to diagnoses/results and nursing interventions) and 2,440 primitive concepts. $^{7}$

ICNP $^{\circledR}$ Research and Development Center of Brazil, located in the city of João Pessoa - Paraíba, has been contributing to the development of the Classification through dissertations and theses. ${ }^{8}$ When using $\mathrm{ICNP}^{\circledR}$, nurses around the world are involved in the identification, validation and cross-mapping of concepts/terms in the records, official publications/care guidelines and in the Classification itself, collaborating to improve terminology, with a focus on specific populations/priorities, in varying levels of health care.

Specialized nursing terminologies were evidenced in the literature for various care groups with limits in Primary Health Care as community elderly, ${ }^{9}$ elderly women with HIV $/ A I D S^{10}$ and people with ostomies, ${ }^{11}$ with scarcity of studies related to the person with metabolic syndrome in the referred level of health care.

Thus, the selection of this syndrome is justified as a priority chosen by this study, inserted in Primary Health Care, locusfor preventing cardiovascular diseases and health promotion, guided by a specialized terminology to be implemented in the health information systems in the future and with a possible positive impact on the measurement of nursing care for people with aggregation of cardiovascular risk factors.

Considering the above, it was asked: of the concepts/terms identified in publications involving the metabolic syndrome, which are valid to constitute specialized terminology that leads to the practice of care and the effective registration of nursing in Primary Health Care? Therefore, the objective was to build a specialized nursing terminology for the care of people with metabolic syndrome in Primary Health Care.

\section{METHOD}

Methodological study, carried out between the years 2016 and 2018, by a group of researchers from Postgraduate Nursing Programs at two Universities in Northeastern Brazil and the ICNP $^{\circledR}$ Research and Development Center ${ }^{\circledR}$ of Brazil. To build the specialized terminology of this study, the steps were followed based on the Brazilian recommendations involving studies with $\mathrm{ICNP}^{\circledR: 3}$ 1) identification of nursing concepts/terms for the care of people with metabolic syndrome; 2) validation by a group of specialist nurses as to the relevance of the identified concepts/terms; and 3) cross-mapping of concepts/terms validated with ICNP ${ }^{\circledR}$.

The first stage involved the identification of official publications/care guidelines with clinical and cultural relevance for nursing practice, aligned with the Theoretical Framework of basic human needs ${ }^{12}$ of people with the syndrome - health priority - in the three levels of psychic life: Psychobiological, psychosocial and psycho-spiritual. This stage occurred in two moments, due to the fact that, when analyzing the concepts of the publications/guidelines selected in the first moment, it was evidenced that they mostly contemplated the psychobiological and psychosocial needs, demanding a new search for publications covering the psycho-spiritual demands of people with metabolic syndrome.

The literature search process, in both moments, occurred through a narrative review of official publications/national guidelines and scientific articles, simultaneously by two master's students, with the help of a third researcher, doctor in nursing and with experience in cardiovascular care with people with metabolic syndrome, in order to identify publications involving relevant state of the art data to contribute to the selection of concepts/terms 
relevant to the clinical practice of nurses in the three levels of psychic life, once the scarcity of related terms is evidenced, mainly, to the psycho-spiritual sphere.

In the first search, official publications related to metabolic syndrome and cardiovascular prevention were identified. In the second moment, the Health Sciences Descriptors were used: Nursing, Spirituality and Religion, crossed, simultaneously, from the Boolean operator "AND" and applied in the search platform of the Virtual Health Library. The inclusion criteria for selection were used: Publications and articles in Portuguese, due to the concept/term extraction tool recognizing only concepts in that language; official article or publication available, free and original, given the fact that the reviews are very extensive and repetitive and highlight ideas present in original studies; published from 2005 to 2016. At the end, four official publications/guidelines ${ }^{13-16}$ and eight scientific articles, ${ }^{17-24}$ totaling 12 files to extract the relevant concepts/terms for nursing care directed to people with metabolic syndrome.

The concepts/terms were extracted by PORONTO, ${ }^{25}$ a computational tool for semiautomatic construction of ontologies in the health field from texts in Portuguese which provides the respective appearance frequencies, exporting them to an Excel for Windows ${ }^{\circledR}$. The use of this tool facilitates the process of normalization and standardization with analysis and exclusion of synonyms, in which concepts/terms are synonymous with different words and expressions with similar meaning, according to Portuguese-language dictionaries. Verbs and grammatical genders were also adapted, excluding concepts/terms belonging to other areas, such as diagnoses and medical procedures or other health professions.

After this process, operational definitions were constructed for the standardized concepts/terms, using ICNP ${ }^{\circledast}$, scientific articles and dictionaries in Portuguese and technical health terms, facilitating subsequent validation by specialists. The construction of the operational definitions took place according to the steps recommended by the literature:261) development of a preliminary definition;2) literature review 3 ) developing identification of specific characteristics; 4) mapping the meaning of the concept; and 5) statement of the operational definition.

In the second stage, the consensus validation technique, ${ }^{27}$ which proposes analysis of the concepts/terms and respective definitions by a particular group of clinical nurses, minimum of three and maximum of five participants, with the purpose of consolidating a consensual opinion (100\%) of experts on the pertinence and relevance of each concept/term. The disagreement of one or more specialists led to the non-validation of concepts/terms extracted and the consequent exclusion of terminology. The inclusion criteria for the specialists were: Nurse, author, co-author or advisor of studies involving metabolic syndrome, and with at least four years of clinical practice with people with health priority. Three specialists were selected through the Platform Lattes considering the geographical proximity for the face-to-face meetings.
The validation took place in a municipality of Cariri Cearense, in which the same specialists participated in the two face-to-face meetings, with the help of two guiding scripts, one involving the validation of the concepts related to the psychobiological and psychosocial dimensions, and the other the concepts of the psychospiritual dimension, both analyzed by the same specialists and conducted by two researchers. The list of valid concepts for nursing care in relation to the elected health priority was consolidated, considering all dimensions of basic human needs.

The third stage included the mapping of concepts previously validated with the primitive concepts of the Seven Axis Model of $\mathrm{ICNP}^{\circledR}$, comparing them and deciding on semantic equivalence and exclusion of synonyms, identifying similarity and enabling adaptation to standardized terminology. This step was based on the Norm ISO $12300: 2016^{28}$ that displays the mapping process and its fundamental purposes to provide support for creating clinical terminologies or subsets of specific use, supporting the methodological proposal with the proposal for this stage of the study.

At the time, after the validation of the concepts of this study, the 2015 version of ICNP ${ }^{\circledR}$, with which a first cross-mapping was carried out, and then the 2017 version was launched. The standard ${ }^{28}$ highlights among its principles that the mappings must have continuous improvement processes, as well as be maintained and regularly updated throughout their life cycle. It was considered necessary to update with this new version and, therefore, to carry out a new mapping, which did not show divergences between the concepts/terms contained between the two referred versions of $I \mathrm{CNP}^{\circledR}$ that makes up the specialized terminology.

For this purpose, two spreadsheets were constructed in Excel for Windows ${ }^{\circledR}$, one with the identified and validated concepts, and the other with the primitive concepts of ICNP ${ }^{\circledR} 2017$, being crossed with each other using the program Access for Windows ${ }^{\circledR}$, to identify the primitive concepts that are constant and not constant in the 2017 version of the Classification. In this mapping process, non-constant concepts were analyzed for similarity and scope in relation to the primitive concepts contained in ICNP ${ }^{\circledR}$ 2017, enabling the framing of terms in the Seven Axes of the Classification Model. In the end, the primitive concepts were validated and mapped from specialized nursing terminology related to the care of people with metabolic syndrome, constant and not constant in the ICNP ${ }^{\circledR} 2017$.

The results were analyzed descriptively regarding the absolute and relative frequency of the concepts, occurrence and constancy or not in the Seven Axes of ICNP ${ }^{\circledR}$, organized in tables and identified with the respective codes extracted from the ICNP ${ }^{\circledR}$ to facilitate the understanding and checking of data, these discussed through national and international literature related to the theme. ${ }^{29}$

This study was approved on 01/27/2016 by the Research Ethics Committee of Universidade Regional do Cariri, according to opinion No.1.396.193, where all specialist nurses signed the informed consent form, following the recommendations of the Resolution 466/2012, of the National Health Council. 


\section{RESULTS}

54,847 concepts were extracted from the selected publications, which were submitted to the process of excluding repetitions, normalization and standardization in relation to ICNP ${ }^{\circledR} 2017$. In the end, there were 489 concepts involving the psychobiological, psychosocial $(n=378)$ and psychospiritual $(n=111)$ needs of people with metabolic syndrome.

Of the total of standardized and standardized concepts, 441 were validated and subjected to similarity and comprehension analysis, which made possible the elimination of synonyms, culminating in 389 primitive concepts related to psychobiological $(n=207)$, psychosocial needs $(n=121)$ and psychospiritual $(n=61)$ of people with metabolic syndrome. After cross-mapping, it became clear that $56.3 \%$ of the validated concepts were contained in ICNP $^{\circledR}$ 2017, as submitted in Chart 1.

As for the constant primitive concepts, those related to the Focus (44.7\%) and Action (31.1\%) axes prevailed, followed respectively by the Judgment (6.8\%), Location (5\%), Means (4.6), Time (4.1\%) and Client (3.7\%) axes. Concerning the non-constant concepts, those related to the Action (56.5\%) and Focus (21.8\%) axes prevailed, followed respectively by the Judgment $(14.7 \%)$, Time (3.5\%) and Means (3, 5\%) (Chart 2).

Chart 1. Concepts validated for the care directed to the person with metabolic syndrome, listed in ICNP ${ }^{\circledR} 2017$. João Pessoa, Brazil, 2018.

\begin{tabular}{|c|c|c|}
\hline AXLES & $\mathbf{N}^{*}$ & CONSTANT CONCEPTS ( $\mathrm{N}=\mathbf{2 1 9}$ ) \\
\hline Focus & $(n=98)$ & 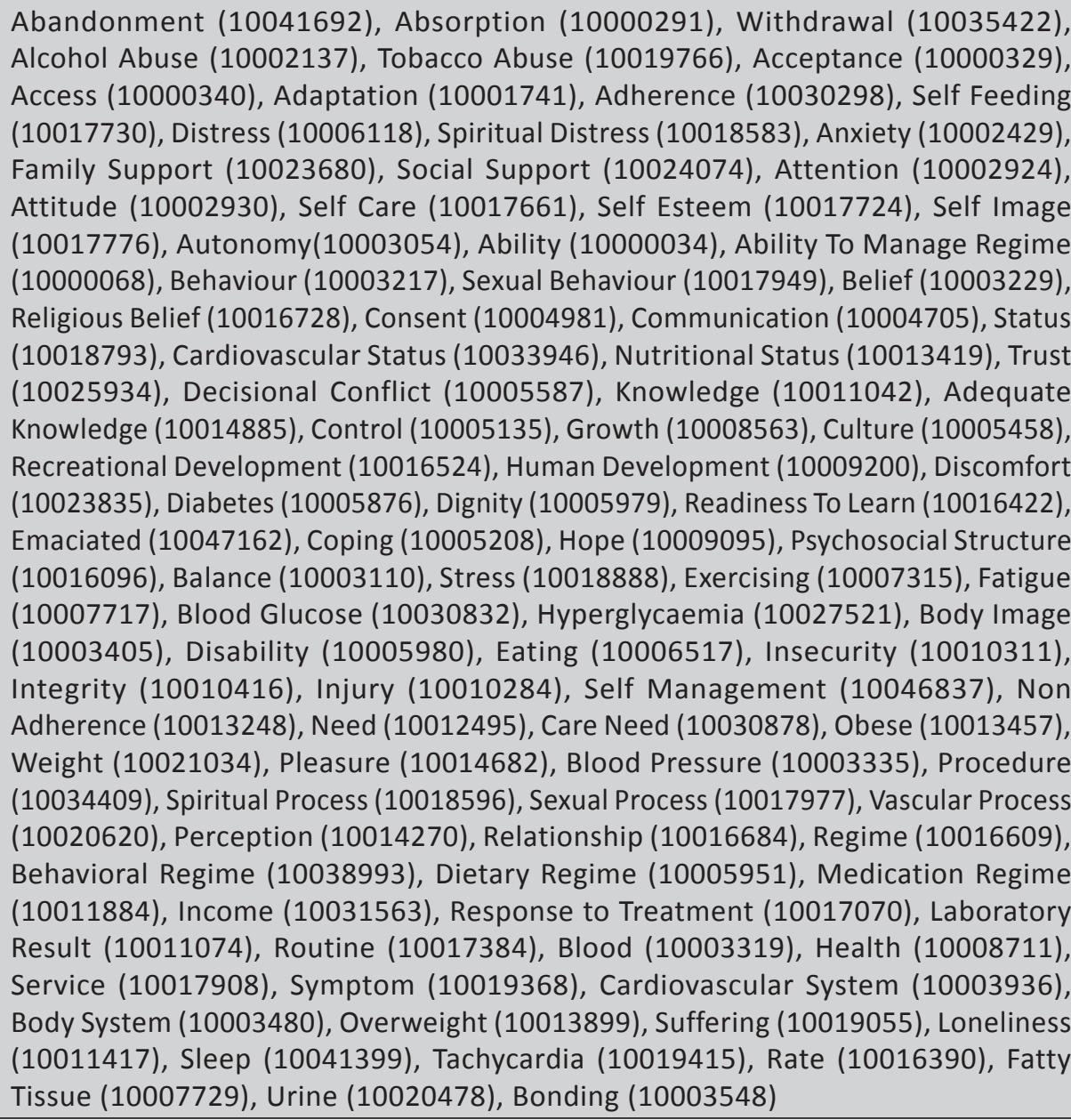 \\
\hline Judgment & $(n=15)$ & $\begin{array}{l}\text { High (10009007), Low (10011438), Dependence (10026671), Large (10011116), Mild } \\
\text { (10025854), Improved (10026692), Moderate (10025865), Negative (10010981), } \\
\text { Small (10018315), Positive (10010981), Impaired (10012938), Actual (10000420), Risk } \\
\text { (10015007), Severe (10025877), Simple (10024061) }\end{array}$ \\
\hline
\end{tabular}

${ }^{*} \mathrm{~N}$ : absolute number. 
Chart 1. Continued...

\begin{tabular}{|c|c|c|}
\hline AXLES & $\mathbf{N}^{*}$ & CONSTANT CONCEPTS ( $\mathrm{N}=\mathbf{2 1 9}$ ) \\
\hline Action & $(n=68)$ & $\begin{array}{l}\text { Accompanying (10042609), Counselling (10005254), Scheduling (10017528), Adjusting } \\
\text { (10001760), Alleviating (10002171), Altering (10002185), Analysing (10002298), Appling } \\
\text { (10002464), Supporting (10019142), Attending (10002911), Increasing (10009961), } \\
\text { Auscultating (10003012), Assisting (10002850), Evaluating (10007066), Calculating } \\
\text { (10003818), Collecting (10004574), Place Or Or In (10016201), Verifying (10020727), } \\
\text { Consulting (10005017), Cutting (10005491), Caretaking (10004002), Collaborating } \\
\text { (10004542), Controlling (10005142), Demonstrating (10005713), Describing (10005797), } \\
\text { Developing (10005848), Decreasing (10005600), Documenting (10006173), Educating } \\
\text { (10006564), Praising (10015409), Referring (10016576), Encouraging (10006823), } \\
\text { Contracting (10005119), Involving (10010877), Establishing (10024813), Stimulating } \\
\text { (10018842), Avoiding (10003077), Examining (10007256), Facilitating (10007499), } \\
\text { Advancing (10001901), Ensuring (10006950), Identifying (10009631), Implementing } \\
\text { (10009840), Initiating (10010221), Handling (10041830), Maintaining (10011504), } \\
\text { Measuring (10011813), Minimizing (10012080), Monitoring (10012154), Motivating } \\
\text { (10012242), Observing (10013474), Obtaining (10013572), Offering (10013636), } \\
\text { Organizing (10013806), Teaching (10019502), Listening (10011383), Participation } \\
\text { (10014099), Planning (10014648), Preventing (10015620), Prioritizing (10015736), } \\
\text { Providing (10015935), Reinforcing (10016650), Recording (10016498), Removing } \\
\text { (10016763), Requesting (10016873), Responding (10017004), Restoring (10017140), } \\
\text { Transporting (10020076), Changing (10004162) }\end{array}$ \\
\hline Time & $(n=9)$ & $\begin{array}{l}\text { Continuous (10005086), Chronic (10004395), Frequency (10008234), Onset (10013689), } \\
\text { Morning (10012226), Present (10015581), Situation (10018202), Afternoon (10001955), } \\
\text { Home Visit (10009082) }\end{array}$ \\
\hline Means & $(n=10)$ & $\begin{array}{l}\text { Food (10008089), Drink (10006269), Clinical Pathway (10004463), Interprofessional } \\
\text { Team (10039400), Intervention (10010535), Plan (10014630), Meal (10011809), Nursing } \\
\text { Service (10013380), Nutrient (10013398), Health Promotion Service (10008776) }\end{array}$ \\
\hline Location & $(n=11)$ & $\begin{array}{l}\text { Abdomen (10000023), Capillary (10003860), School (10017537), Neck (10012476), } \\
\text { Position (10014788), Lung (10011486), Kidney (10022439), Skin (10018239), Muscle } \\
\text { (10012290), Outpatient Department (10013852), Health Care Unit (10008724) }\end{array}$ \\
\hline Client & $(n=8)$ & $\begin{array}{l}\text { Adult (10001889), Community (0004733), Child (10004266), Caregiver (10003958), } \\
\text { Family (10007554), Group (10008544), Individual (10010018), Patient (10014132) }\end{array}$ \\
\hline
\end{tabular}

${ }^{*} \mathrm{~N}$ : absolute number.

Chart 2. Validated concepts for the care directed to the person with metabolic syndrome, not constant in ICNP ${ }^{\circledR} 2017$. João Pessoa, Brasil, 2018.

\begin{tabular}{|c|c|l|}
\hline AXELS & N* & \multicolumn{1}{c|}{ NON-CONSTANT CONCEPTS (N=170) } \\
\hline Focus & & $\begin{array}{l}\text { Welcome, Affectivity, Skills, Self Knowledge, Well Being, Cephalalgia, Abdominal } \\
\text { circumference, Costume, Constraint, Desire, Disease, Understanding, Enthusiasm, Effort, } \\
\text { Sport, Life style, Eutrophic, Life Expectation, Faith, Weighed gain, Hypercholesterolemia, } \\
\text { Hyperinsulinemia, Hypertriglyceridemia, Body mass index, Holistic, Paying, Palpitation, } \\
\text { Peace, Perseverance, Claim, Reflection, Repose, Serenity, Feeling, Metabolic syndrome, } \\
\text { Socioeconomic, Awe, Therapeutic }\end{array}$ \\
\hline Judgment & $(\mathrm{n}=37)$ & $\begin{array}{l}\text { Shaken, Altered, Active, Basic, Good, Conflicting, Short, Unfavorable, Elevated, Rare, } \\
\text { Spontaneous, Equivalent, Failure, Inadequate, Incomplete, Long, Major, Minor, Insufficient, } \\
\text { Premature, Prolonged, Rigorous, Scared, Satisfactory, Sedentary }\end{array}$ \\
\hline
\end{tabular}

${ }^{*} \mathrm{~N}$ : absolute number. 
Chart 2. Continued...

\begin{tabular}{|c|c|c|}
\hline AXELS & $\mathbf{N}^{*}$ & NON-CONSTANT CONCEPTS ( $\mathrm{N}=170)$ \\
\hline Action & $(n=96)$ & $\begin{array}{l}\text { Add, Acquiring, Grouping, Expanding, Improving, Abolishing, Approaching, Adapting, } \\
\text { Adopting, Alerting, Alternating, Supporting, Pointing, Presenting, Appropriating, } \\
\text { Arguing, Associating, Attending, Achieving, Classifying, Sharing, Understanding, } \\
\text { Achieving, Accomplishing, Checking, Combining, Comparing, Complementing, } \\
\text { Composing, Conducting, Contemplating, Considering, Constituting, Contributing, } \\
\text { Defining, Discouraging, Highlighting, Detecting, Discussing, Teaching, Understanding, } \\
\text { Listening, Stratifying, Choosing, Specifying, Elaborating, Emphasizing, Facing, Delivering, } \\
\text { Involving, Clarifying, Estimating, Strengthening, Guaranteeing, Encouraging, Inserting, } \\
\text { Intervening, Listing, Modifying, Pacting, Persisting, Enabling, Practicing, Propitiating, } \\
\text { Extending, Proposing, Providing, Quantifying, Questioning, Readjusting, Reassessing, } \\
\text { Accomplishing, Removing, Resuming, Recommending, Recognizing, Redefining, } \\
\text { Reducing, Reorganizing, Reorienting, Rethinking, Repeating, Respecting, Accountabling, } \\
\text { Emphasizing, Restoring, Restricting, Selecting, Sensitizing, Emphasizing, Simplifying, } \\
\text { Requesting, Replacing, Synthesizing, Suggesting, Enhancing }\end{array}$ \\
\hline Time & $(n=6)$ & Schedule, Integral, Limit, Term, Periodic, Rapid \\
\hline Means & $(n=6)$ & Counseling, Artificial, Activity, Dialogue, Interview, Way \\
\hline Location & - & In this axis, the concepts identified and validated are contained in ICNP ${ }^{\circledR} 2017$ \\
\hline Client & - & In this axis, the concepts identified and validated are contained in ICNP ${ }^{\circledR} 2017$ \\
\hline
\end{tabular}

*N: absolute number.

Of the total of constant and non-constant concepts $43.2 \%$ were or were classified in the Action axis, followed by the Focus axis (34\%). The concepts highlighted in Chart 2 are contained in ICNP ${ }^{\circledR} 2017$ as specifying concepts, but not as primitive concepts with specific code.

\section{DISCUSSION}

The communication of a discipline/profession, with society, between themselves or other members of a certain area, goes through the question of how knowledge is organize, ${ }^{30}$ being in a continuous evolution process, expressed by concepts/terms that represent the relevant phenomena. In this study, due to the large number of concepts/terms extracted from the empirical bases, the process of normalization and standardization collaborated with the refinement and organization of nursing terminology for the care of people with metabolic syndrome Considering the publication of the 2019 version of ICNP ${ }^{\circledR}$, there was no disagreement between the concepts of this terminology as to the constancy in the current version, as well as no non-constant concept was inserted in the current Classification version. ${ }^{7}$

The concepts extracted, especially the most frequent ones, such as health, risk, blood pressure, well being, belief, self care, lifestyle, and the concept of the priority of this study, metabolic syndrome, are inserted in the field of action of nurses in Primary Health Care, involving basic human needs in all its dimensions. The most frequent concepts are mostly linked to ICNP ${ }^{\circledR}$, fundamental instrument of the work process that includes concepts that describe the important phenomena of the profession in a uniform way, collaborating for the development of Nursing and demonstrating contribution in health care. ${ }^{31}$

Employing concepts inserted in a classification system, whether for teaching, research or assistance collaborates in improving the quality of nursing records, enables continuity of care, consistency in communication and increased safety for those involved in the care process, ${ }^{32}$ converging with the purpose of this study, in which the specialized nursing terminology constructed can integrate several instruments, information systems and theoretical models.

In the context of Primary Health Care, due to the specific duties of the nurse, instruments and methods directed to the systematization of care are required, above all, compatible with the assumptions of collective health, using information technologies for operationalization, documentation and planning of actions in health ${ }^{33}$ Thus, the nurse who works in Primary Health Care can use the concepts of the terminology built in this study to carry out the nursing records from the consultation with the person with metabolic syndrome, as well as develop assessment or measurement instruments for use in clinical practice, with an impact on the quality of care and subsidizing the generation of health and nursing indicators.

Due to the difficulty of this study to highlight conceptslterms of care for people with metabolic syndrome in nursing records from practice, the validation process was essential to verify the relevance of the conceptsiterms extracted in relation to the theme, influencing what is referred to by the authors ${ }^{32}$ that although the terminologies present universal concepts/terms, they must be adapted to the reality and regional, institutional and cultural 
particularities of each population, in order to be recognized by the professionals who will use them.

The validated concepts were mostly inserted in the psychobiological and psychosocial needs, a fact observed in the results of another study involving diabetes mellitus, ${ }^{34}$ relating them to the question that they are more approached and studied in the scientific community, as well as the training that still does not prioritize the biological activity, focused on the disease, widely evident in clinical practice, with a lack of concepts/terms inserted in the psychospiritual needs.

The reduced quantity of concepts in the psycho-spiritual dimension is related to their insufficient recognition in health care, especially in the context of cardiovascular prevention, due, also, to the emphasis on the biomedical model.$^{35}$ Nurses should consider the importance of spiritual care, registering actions through concepts that demonstrate the existence of this dimension and that it is integrated in an integrated way with biological and social, as presented in this study, and not in a segregated way.

When relating validated concepts to the concepts of the Nursing Metaparadigm, there is an interrelation between them, in which the relevant concepts reflect the interaction of the person with metabolic syndrome and the environment of primary care, influenced by nursing care, from the perspective of cardiovascular prevention and health promotion, with the potential to reduce morbidity and mortality from cardiovascular disease and diabetes mellitus type 2. These relevant concepts are organized in order to support the construction of diagnoses/results and nursing interventions for health priority, considering the axes of the Classification and the ISO 18.104:2014 Standard.

Through cross-mapping, there was a predominance of concepts validated as contained in ICNP ${ }^{\circledR 2017}$, mainly involving the Focus axis, in concepts such as food, self care, self image, communication, knowledge, belief, physical exercise, hyperglycemia, food, need, blood pressure, health, overweight As for the non-constant concepts, the concepts of the Action axis prevailed, such as alerting, paying attention, understanding, teaching, encouraging, involving, recommending, reducing, valuing. The concepts mentioned are evident in the literature in the national and international literature. ${ }^{2,13,14,36,37}$

The large number of concepts not included in the Classification stands out, demonstrating the continuous demand for updating to include relevant concepts in nursing care, as proposed in this study. Cross-mapping collaborates with this Classification evolution process and the development of nursing technologies that enable dialogue between different specialties and countries, ${ }^{38}$ for inclusion in health information systems, generating health indicators from nursing practice.

The challenge for Nursing researchers converges with the exposed results, such as the recognition of standardized language systems, as legitimate repositories of concepts created by research ${ }^{30}$ and the unification of these, avoiding (re) work, because if the term was analyzed, there would be a discussion about the adequacy of the proposed definition in relation to the new context, ${ }^{8}$ what this study would collaborate, considering the number of concepts not included in ICNP ${ }^{\circledR} \mathrm{e}$ and their potential use in different contexts of nursing care in cardiology and other related areas.

\section{CONCLUSIONS AND IMPLICATIONS FOR PRACTICE}

It was possible to achieve the proposed objective with the construction of specialized nursing terminology for the care of people with metabolic syndrome, prevailing primitive concepts contained in ICNP ${ }^{\circledR} 2017$, but with significant numbers of non-constant concepts to be inserted in future versions of the Classification. These are mostly inserted in the Focus and Action axes, with an impact on the production of innovative products with the future structuring of a terminology subset of ICNP ${ }^{\circledR}$, aimed at monitoring the health priority in Primary Care, as well as clinical instruments and conceptual models for the person with the syndrome.

The extraction of concepts/terms only from the literature in the area and the choice of general descriptors for the second search directed to the psycho-spiritual need of the human being and their relationship with Nursing, not considering the descriptor metabolic syndrome, are configured as a limitation of this study, due to the possibility of not reflecting all the particularities of nursing care directed to people with metabolic syndrome. However, this fact did not affect the quality of the study, as the concepts were validated by experts, expanding the margin of relationship between the concepts and the elected health priority.

As implications for practice, there is the proposal of an innovative terminology and the advancement of knowledge about the use of Classification in nursing care for people with the syndrome, contributing to the standardization of professional language and the development of Nursing science. With the submitted results, the relevance related to the nursing actions is strengthened, it stimulates critical thinking and clinical reasoning through the use of concepts to identify phenomena, with the potential to increase information systems in Primary Health Care with nursing care indicators for people with aggregation of cardiovascular risk factors.

\section{CONTRIBUTIONS OF THE AUTHORS}

Study conception and design. Data collection, analysis and interpretation. Results discussion. Content writing and/or critical review. Approval of the final version of the article. Responsibility for all aspects of the content and integrity of the published article: Nuno Damácio de Carvalho Félix. Célida Juliana de Oliveira. Maria Miriam Lima da Nóbrega. Study conception and design. Data analysis and interpretation. Results discussion. Content writing and/or critical review. Approval of the final version of the article. Responsibility for all aspects of the content and integrity of the published article: Maria Naiane Rolim Nascimento. Natana de Morais Ramos 


\section{ASSOCIATED EDITOR}

\author{
Cândida Caniçali Primo
}

\section{REFERENCES}

1. Félix NDC, Nóbrega MML. Metabolic syndrome: conceptual analysis in the nursing context. Rev Lat Am Enfermagem. 2019;27:e3154. PMid:31432914.

2. Carvalho-Vidigal F, Bressan J, Babio N, Salas-Salvadó J. Prevalence of metabolic syndrome in Brazilian adults: a systematic review. BMC Public Health. 2013;13(1198):1. http://dx.doi.org/10.1186/1471-245813-1198. PMid:24350922.

3. Nóbrega MML, Cubas MR, Egry EY, Nogueira LGF, Carvalho CMG, Albuquerque LM. Desenvolvimento de subconjuntos terminológicos da CIPE ${ }^{\circledR}$ no Brasil. In: Cubas MR, Nóbrega MML, organizadores. Atenção Primária em Saúde: diagnósticos, resultados e intervenções. Rio de Janeiro: Elsevier; 2015. p. 3-8.

4. Pires DEP. Necessary changes for advancing Nursing as caring science. Rev Bras Enferm. 2013;66(spe):39-44. http://dx.doi.org/10.1590/S003471672013000700005 .

5. Clares JWB, Freitas MC, Guedes MVC, Nóbrega MML. Construction of terminology subsets: contributions to clinical nursing practice. Rev Esc Enferm USP. 2013;47(4):965-70. http://dx.doi.org/10.1590/S0080623420130000400027. PMid:24310697.

6. Garcia TR, Bartz CC, Coenen AM. CIPE ${ }^{\circledR}$ : uma linguagem padronizada para a prática profissional. In: Garcia TR, organizador. Classificação Internacional para a Prática de Enfermagem (CIPE ${ }^{\circledR}$ ): versão 2017. Porto Alegre: Artmed; 2017. p. 24-39.

7. Garcia TR, Nóbrega MML, Cubas MR. Classificação Internacional de Prática de Enfermagem - CIPE ${ }^{\circledR}$ : versão 2019 [Internet]. João Pessoa: Centro de Pesquisa e Desenvolvimento da CIPE ${ }^{\circledR}$, Universidade Federa da Paraíba; 2019 [citado 2020 Jan 03]. Disponível em: https://www.icn. ch/what-we-do/projects/ehealth/icnp-download/icnp-translations

8. Carvalho CMG, Cubas MR, Nóbrega MML. Brazilian method for the development terminological subsets of ICNP ${ }^{\circledR}$ : limits and potentialities Rev Bras Enferm. 2017;70(2):430-5. http://dx.doi.org/10.1590/00347167-2016-0308. PMid:28403281.

9. Clares JBW, Nóbrega MML, Guedes MVC, Silva LF, Freitas MC. Bank of terms for clinical nursing practice with community elderly. Rev. Eletr. Enf. 2016;18:e1167. http://dx.doi.org/10.5216/ree.v18.37759.

10. Siqueira MCF, Bittencourt GKGD, Nóbrega MML, Nogueira JA, Silva AO. Term base for nursing practices with elderly women with HIV/AIDS. Rev Gaúcha Enferm. 2015;36(1):28-34. http://dx.doi.org/10.1590/19831447.2015.01.46671. PMid:26098799.

11. Carvalho CMG, Cubas MR, Nóbrega MML. Terms of the specialized nursing language for the care of ostomates. Rev Bras Enferm. 2017;70(3):461-7. http://dx.doi.org/10.1590/0034-7167-2015-0058. PMid:28562791.

12. Horta WA. Processo de enfermagem. Rio de Janeiro: Guanabara Koogan; 2011.

13. Sociedade Brasileira de Cardiologia. I Diretriz brasileira de diagnóstico e tratamento da síndrome metabólica. Arq Bras Cardiol. 2005;84(Supl. 1):3-28. http://dx.doi.org/10.1590/S0066-782X2005000700001.

14. Simão AF, Precoma DB, Andrade JP, Correa Fo H, Saraiva JFK, Oliveira GMM et al. I Diretriz Brasileira de Prevenção Cardiovascular Arq Bras Cardiol. 2013;101(6, Supl. 2):1-63. http://dx.doi.org/10.5935/ abc.2013S012. PMid:24554026.

15. Ministério da Saúde (BR), Secretaria de Atenção à Saúde, Departamento de Atenção Básica. Diretrizes para o cuidado das pessoas com doenças crônicas nas redes de atenção à saúde e nas linhas de cuidado prioritárias. [Internet]. Brasília: Ministério da Saúde; 2013 [citado 2016 Mar 18]. Disponível em: http://bvsms.saude.gov.br/bvs/publicacoes/ diretrizes\%20_cuidado_pessoas\%20_doencas_cronicas.pdf

16. Ministério da Saúde (BR), Secretaria de Atenção à Saúde, Departamento de Atenção Básica. Estratégias para o cuidado da pessoa com doença crônica. [Internet]. Brasília: Ministério da Saúde; 2014 [citado 2016 Mar 28]. Disponível em: http://bvsms.saude.gov.br/bvs/publicacoes/ estrategias_cuidado_pessoa_doenca_cronica_cab35.pdf
17. Chaves ECL, Carvalho EC, Hass VJ. Validation of the nursing diagnosis Spiritual Anguish: analysis by experts. Acta Paul Enferm. 2010;23(2):26470. http://dx.doi.org/10.1590/S0103-21002010000200018.

18. Cortez EA, Teixeira ER. The nurse in face of the client's religiosity. Rev Enferm UERJ [Internet]. 2010; [citado 2016 abr 23];18(1):114-9. Disponivel em: http://www.facenf.uerj.br/v18n1/v18n1a20.pdf

19. Ferreira AGN, Gubert FA, Martins AKL, Galvão MTG, Vieira NFC, Pinheiro PNC. Health promotion in the religious scenario: opportunities for nursing care. Rev Gaúcha Enferm. 2011;32(4):744-50. http://dx.doi. org/10.1590/S1983-14472011000400015. PMid:22299277.

20. Pedrão RB, Beresin R. Nursing and spirituality. Einstein. 2010;8(1):86-91 http://dx.doi.org/10.1590/s1679-45082010ao1208. PMid:26761758.

21. Penha RM, Silva MJP. Meaning of spirituality for critical care nursing Texto Contexto Enferm. 2012;21(2):260-8. http://dx.doi.org/10.1590/ S0104-07072012000200002.

22. Ponte KMA, Silva LF, Aragão AEA, Guedes MVC, Zagonel IPS. Contribution of nursing clinical care for psycho-spiritual comfort of women with acute myocardial infarction. Esc Anna Nery. 2012;16(4):666-73. http://dx.doi. org/10.1590/S1414-81452012000400004

23. Schleder LP, Parejo LS, Puggina AC, Silva MJP. Spirituality of relatives of patients hospitalized in intensive care unit. Acta Paul Enferm. 2013;26(1):71-8. http://dx.doi.org/10.1590/S0103-21002013000100012.

24. Soares AN, Morgan BS, Santos FBO, Matozinhos FP, Penna CMM Everyday health-related beliefs and practices among primary health care users. Rev Enferm UERJ [Internet]. 2014; [citado 2016 ago 5];22(1):83-8. Disponível em: http://www.e-publicacoes.uerj.br/index. php/enfermagemuerj/article/view/11450

25. Zahfra FM, Carvalho DR, Malucelli A. Poronto: tool for semi-automatic ontology construction in portuguese. J Health Inform [Internet]. 2013 [citado 2016 fev 1];5(2):52-9. Disponível em: http://www.jhi-sbis.saude. ws/ojs-jhi/index.php/jhi-sbis/article/view/232/167

26. Lenz E. Basic principles of measurement: operationalizing nursing concepts. In:Waltz CF, Strickland OL, Lenz E, organizadores. Measurement in nursing and health research. 5th ed. New York: Springer Publishing Company; 2017.632 p.

27. Carlson J. Consensus validation process: a standardized research method to identify and link the relevant NANDA, NIC, and NOC terms for local populations. Int J Nurs Terminol Classif [Internet]. 2006; [citado 2016 nov 22];17(1):23-4. Disponível em: https://www.ncbi.nlm.nih.gov/ pubmed/17117929

28. International Organization for Standardization. ISO 12300: health informatics: principles of mapping between terminological systems. Genebra: ISO; 2016. p. 1-46.

29. International Council of Nurses. ICNP Browser [Internet]. Geneva, Switzerland: ICNP; 2019 [cited 2019 Dec 22]. Available from: https:// www.icn.ch/what-we-do/projects/ehealth/icnp-browser

30. Carvalho EC, Cruz DALM, Herdman TH. Contribution of standardized languages for knowledge production, clinical reasoning and clinical Nursing practice. Rev Bras Enferm. 2013;66(spe):134-41. http://dx.doi. org/10.1590/S0034-71672013000700017. PMid:24092320.

31. Barra DCC, Dal Sasso GTMD. Data standards, terminology and classification systems for caring in health and nursing. Rev Bras Enferm. 2011;64(6):1141-9. http://dx.doi.org/10.1590/S0034-71672011000600023. PMid:22664615.

32. Silva ERR, Cavalcanti ACD, Caldas MCRG, Lucena AF, Almeida MA, Linch GFC et al. Advanced nursing process quality: comparing the International Classification for Nursing Practice (ICNP) with the NANDA International (NANDA? I) and Nursing Interventions Classification (NIC). J Clin Nurs. 2017;26(3-4):379-87. http://dx.doi.org/10.1111/jocn.13387. PMid:27192041.

33. Cavalcante MDMA, Larocca LM, Chaves MMN, Cubas MR, Piosiadlo LCM, Mazza VA. Nursing terminology as a work process instrument of nurses in collective health. Rev Esc Enferm USP. 2016;50(4):610-6. http:// dx.doi.org/10.1590/S0080-623420160000500010. PMid:27680046.

34. Nogueira LGF, Nóbrega MML. Construction and validation of nursing diagnoses for individuals with diabetes in specialized care. Rev Esc Enferm USP. 2015;49(1):54-60. http://dx.doi.org/10.1590/S0080623420150000100007. PMid:25789642. 
35. Castro MC, Fuly PS, Garcia TR, Santos ML. ICNP ${ }^{\circledR}$ terminological subgroup for palliative care patients with malignant tumor wounds. Acta Paul Enferm. 2016;29(3):340-6. http://dx.doi.org/10.1590/19820194201600047.

36. Saboya PP, Bodanese LC, Zimmermann PR, Gustavo AS, Assumpção $\mathrm{CM}$, Londero F. Metabolic syndrome and quality of life: a systematic review. Rev Lat Am Enfermagem. 2016;24(0):e2848. http://dx.doi. org/10.1590/1518-8345.1573.2848. PMid:27901223.
37. Scuteri A, Laurent S, Cucca F, Cockcroft J, Cunha PG, Mañas LR et al. Metabolic syndrome across europe: different clusters of risk factors. Eur J Prev Cardiol. 2015;22(4):486-91. http://dx.doi. org/10.1177/2047487314525529. PMid:24647805.

38. Bonfim D, Gaidzinski RR, Santos FM, Gonçales CS, Fugulin FMT. The identification of nursing interventions in primary health care: a parameter for personnel staffing. Rev Esc Enferm USP. 2012;46(6):1462-70. http:// dx.doi.org/10.1590/S0080-62342012000600025. PMid:23380792. 